\title{
The effects of pregnancy and lactation on copper and zinc retention in the rat
}

\author{
By R. B. WILLIAMS, N. T. DAVIES AND I. MCDONALD \\ Rowett Research Institute, Bucksburn, Aberdeen AB2 9SB
}

(Received 22 November 1976 - Accepted 5 April 1977)

1. The accretion of copper and zinc in maternal tissues, conception products and postnatal offspring of the rat was determined at different stages of pregnancy and lactation.

2. Equations relating the weight of the bodies of the developing young and of the amounts of $\mathrm{Cu}$ and $\mathrm{Zn}$ in them to the time that has elapsed since conception showed that, early in pregnancy, the specific rates of accretion of $\mathrm{Cu}$ or $\mathrm{Zn}$ were greater than that of weight, but declined more rapidly as development continued. The instantaneous rates of accretion of both metals rose throughout pregnancy but only that of $\mathrm{Cu}$ continued to increase during lactation.

3. The amount of $\mathrm{Cu}$ in the maternal body rose significantly during pregnancy and declined thereafter, but relatively small changes in its $\mathrm{Zn}$ content occurred.

4. The results are discussed in relation to the relative demands for these metals during pregnancy and lactation.

The pregnant and lactating rat has been the subject of numerous studies of the effects of pregnancy and lactation on the chemical composition of mother and offspring (Spray, 1950; Spray \& Widdowson, 1950). Most recent studies have concentrated on the biochemical and physiological consequences of deficiencies or excesses of essential trace metals, but few attempts have been made to delineate those stages of pregnancy and lactation at which marginal deficiencies of essential metals may have the most profound effect on the development of foetus and postnatal offspring.

This initial study on the rat was designed to determine the relative demands for copper and zinc in different stages of pregnancy and lactation.

\section{EXPERIMENTAL}

Hooded Lister female rats of the Rowett Institute strain were raised from weaning in polypropylene/stainless steel cages and were fed a stock colony diet ('Oxoid'; H. C. Styles, Bewdley, Worcs), which contained about 100 and $20 \mathrm{mg} / \mathrm{kg}$ respectively of $\mathrm{Zn}$ and $\mathrm{Cu}$, until they reached a weight of approximately $230 \mathrm{~g}$. At this stage oestrus was induced by the method of May \& Simpson (1971), after which all but six animals were allowed to mate with stock colony males. The $24 \mathrm{~h}$ period following the appearance of copulation plugs was regarded as day 1 of pregnancy. At intervals (indicated in Table 1), groups of five or six animals were killed by inhalation of ether vapour and stored at $-20^{\circ}$ in polythene bags until they were prepared for analysis. All animals had unlimited access to food and water.

After thawing each animal, the unopened uterus and the entire digestive tract were removed. The contents of the latter were cleaned out and the empty tract was then replaced in the body which was weighed to give the 'empty' weight. The liver and one femur were then dissected out, weighed and analysed separately for $\mathrm{Zn}$ and $\mathrm{Cu}$; the amounts found were added to that determined in the remainder of the carcase to give the total amount of $\mathrm{Zn}$ and $\mathrm{Cu}$ in the maternal body.

In this experiment, the uteri removed from those animals killed at day 12 of pregnancy 
were weighed and analysed unopened as separate values for the weight of the uterus, placentae and foetuses, and the amounts of $\mathrm{Cu}$ and $\mathrm{Zn}$ in them had been determined in an earlier experiment. In that experiment when the foetuses and placentae were very small, the uterus was placed on a polythene film before being opened and, with the aid of a dissecting microscope, the foetuses, complete in their amniotic sacs, were gently teased away from the placentae by using glass 'knives' made from fragments of microscope slides. The placentae were detached from the wall of the uterus in the same way. The foetuses from each uterus were then pooled, as were the placentae, weighed and analysed for $\mathrm{Zn}$ and $\mathrm{Cu}$. By these means contamination by metal instruments was obviated. In the present experiment when at later stages of pregnancy the foetuses and placentae were larger, stainless steel instruments were used.

The postnatal offspring were treated as follows: at 2 and $6 \mathrm{~d}$ of age only the contents of the stomach were removed before the young were weighed and analysed, but at $14 \mathrm{~d}$ the contents of the intestinal tract were also removed.

The small quantities of the early foetal and placental material were 'wet ashed' with a mixture of $18 \mathrm{M}-\mathrm{H}_{2} \mathrm{SO}_{4}-16 \mathrm{M}-\mathrm{HNO}_{3}-12 \mathrm{M}-\mathrm{HClO}_{4}(1: 5: 2$, by vol.). All other samples were placed in acid-washed Pyrex glass vessels and dried in a stainless-steel oven at $105^{\circ}$. After preliminary carbonizing over a Bunsen burner they were ashed overnight in a silica-lined furnace at $450^{\circ}$. Any carbon remaining after this treatment was destroyed by the addition of small quantities of $16 \mathrm{M}-\mathrm{HNO}_{3}-11 \mathrm{M}-\mathrm{H}_{2} \mathrm{O}_{2}(1: 1 \mathrm{v} / \mathrm{v})$, followed by gentle heating after which the samples were returned to the furnace. The ashes so formed were dissolved in appropriate volumes of $6 \mathrm{M}-\mathrm{HCl}$. The solutions obtained by both methods of ashing were then diluted further with glass-distilled water and analysed for $\mathrm{Zn}$ and $\mathrm{Cu}$ by atomic absorption spectrophotometry using a Varian AA5 spectrophotometer (Varian Associates Ltd, Walton-on-Thames, Surrey); blank values were determined on acid solutions of the same molar concentrations.

Statistical analysis of the results was derived from a pooled analysis of variance of the individual sets of results.

\section{RESULTS}

The effect of pregnancy and lactation on the weight and content of $\mathrm{Zn}$ and $\mathrm{Cu}$ of the maternal tissues

The wet weights of the maternal tissues and the amounts of $\mathrm{Zn}$ and $\mathrm{Cu}$ found in them are shown in Table 1. It can be seen that, during pregnancy, the empty weight of the maternal body increased so that by day 18 , at which time the highest value was observed, the difference in weight between the rats killed then and those killed on day 0 was highly significant $(P<0.001)$. By day 6 of lactation, however, the rats had lost all the weight they had previously gained. In contrast, the non-mated rats, at the time equivalent to day 14 of lactation, were significantly heavier than at day $0(P<0.001)$.

The amount of $\mathrm{Zn}$ in the maternal body also increased during pregnancy; the rats killed at day 15 contained significantly more $\mathrm{Zn}$ than those killed at the start of the experiment $(P<0.01)$, and although some variation in maternal $\mathrm{Zn}$ content occurred at later stages of pregnancy and during lactation, the amount found was always greater than at day 0 ; at day 14 of lactation the difference was still significant $(P<0.05)$. In the non-mated rats, however, a highly significant increase $(P<0.001)$ had occurred in the amount of $\mathrm{Zn}$ accrued by them, which was, over the whole period examined, equivalent to a mean rate of gain of $30.7 \mu \mathrm{g} \mathrm{Zn} / \mathrm{d}$. This was about three times the rate of gain of $\mathrm{Zn}$ made by the pregnant and lactating rats $(10.5 \mu \mathrm{g} / \mathrm{d})$.

The differences in the rate of retention of $\mathrm{Zn}$ by pregnant and lactating rats as compared with non-mated controls are reflected by differences in the amount of $\mathrm{Zn}$ found in their 


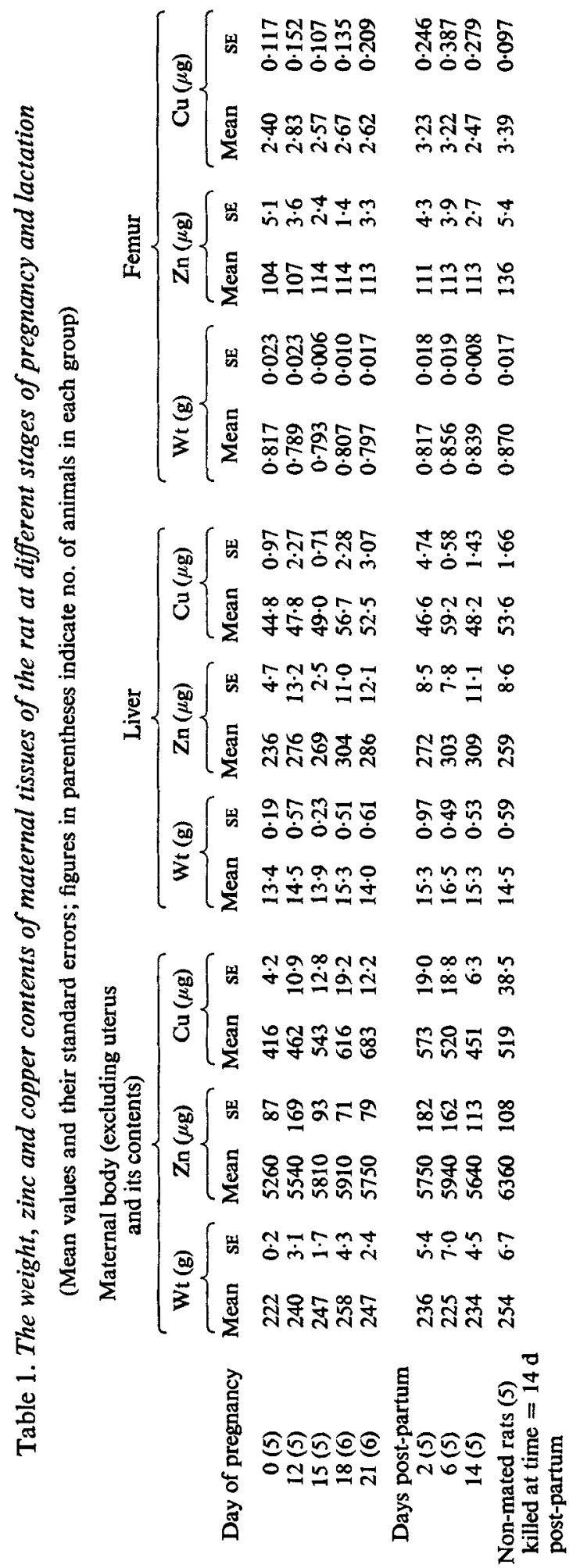


femurs; up to day 15 a small but significant $(P<0.05)$ increase occurred in the $\mathrm{Zn}$ content of the femurs of pregnant animals but no further change took place while, in the nonmated animals killed at the end of the experiment, the amount of $\mathrm{Zn}$ found in their femurs was appreciably more than at day $0(P<0.001)$. These findings suggest that pregnancy and lactation inhibited the age-dependent accretion of $\mathrm{Zn}$ by the female rat.

Changes in the amount of $\mathrm{Cu}$ found in the femurs of these animals were small. is in contrast to the transient increase in the $\mathrm{Cu}$ content of the maternal body which occurred during pregnancy and which, by day 15 , was highly significantly different $(P<0.001)$ from that found in the rats killed at the beginning of the experiment. Even more $\mathrm{Cu}$ was deposited to day 21 of pregnancy but after parturition it was lost rapidly, so that by day 14 of lactation the amount found was similar to that at the beginning of pregnancy. These changes in the maternal body deposits of $\mathrm{Cu}$ were not reflected by any biologically significant differences in the amount of $\mathrm{Cu}$ found in the livers of these animals at any stage of pregnancy or lactation, and the sites at which the $\mathrm{Cu}$ was stored are unknown. Over-all, the increase in the amount of $\mathrm{Cu}$ deposited in the maternal body to day 21 of pregnancy was equivalent to a change in concentration from (mean $\pm \mathrm{SE}$ ) $1.87 \pm 0.02 \mu \mathrm{g} / \mathrm{g}$ wet weight at day 0 to $2.76 \pm 0.05 \mu \mathrm{g} / \mathrm{g}$ at day 21 . This difference was highly significant $(P<0.001)$.

The effects of pregnancy or lactation on 'stores' of $\mathrm{Zn}$ or $\mathrm{Cu}$ in the liver were negligible under the nutritionally-adequate condition of this experiment. Some differences were, however, observed in the weight of the liver. The greatest weights found occurred at day 18 of pregnancy and day 6 of lactation and both values were significantly different from that at day $0(P<0.05$ and $P<0.001$, respectively). Over-all the weight of the liver, as a proportion of 'empty' body-weight increased by about $1 \%$ during lactation.

At any stage of pregnancy examined the amount of $\mathrm{Zn}$ found in the maternal body was not related to the number of foetuses carried, nor at days 12,15 and 18 was the amount of $\mathrm{Cu}$. At day 21 however, a significant relationship $(P<0.05)$ was found to exist between the maternal body $\mathrm{Cu}$ content and foetal number which could be described by the equation $y=12 \cdot 2 x+540$, where $y$ is $\mu \mathrm{g} \mathrm{Cu}$ in the maternal body and $x$ is the number of foetuses (SE of the coefficient $3 \cdot 8$ ). It would appear that, in general, the deposition of $\mathrm{Cu}$ in the maternal body was essentially a consequence of the state of pregnancy, and was not affected by foetal demands.

\section{The effect of stage of pregnancy and foetal number on the weight, $\mathrm{Zn}$ and $\mathrm{Cu}$ contents of the uterus and placenta}

In the present experiment the amounts of $\mathrm{Zn}$ and $\mathrm{Cu}$ in the foetuses, uteri and placentae at day 12 of pregnancy were not measured separately, but were estimated by dividing the total amounts found in the unopened uterus between the three parts in the proportions found in a preliminary experiment; the results of which are shown in Table 2. The total amounts of $\mathrm{Zn}$ and $\mathrm{Cu}$ found in the products of conception at day 12 were very similar in the two experiments.

The concentrations of $\mathrm{Zn}$ and $\mathrm{Cu}$ in the uterus or placenta at any stage of pregnancy were not affected by the number of foetuses carried and, as the total weight of the placentae and the weight of the uterus were proportional to foetal numbers at the same stage of pregnancy, it was possible to calculate what their weights and their contents of $\mathrm{Zn}$ and $\mathrm{Cu}$ would be in a 'standard' rat with a foetal burden of ten young. These results are shown in Table 3, from which it was calculated that, from day 15 to day 21 of pregnancy, the over-all daily rates of deposition of $\mathrm{Zn}$ and $\mathrm{Cu}$ in the uterine-placental complex would be 8.8 and $3.6 \mu \mathrm{g}$ respectively. 
Table 2. The weight and zinc and copper contents of the rat foetus, placenta and uterus on day 12 of pregnancy. (Preliminary expt)

\begin{tabular}{|c|c|c|c|c|c|c|c|}
\hline \multirow[b]{2}{*}{ Rat no. } & \multirow{2}{*}{$\begin{array}{l}\text { No. of } \\
\text { foetuses }\end{array}$} & \multirow[b]{2}{*}{ Total weight (g) } & \multirow{2}{*}{$\begin{array}{l}\text { Mean wt per } \\
\text { foetus (g) }\end{array}$} & \multicolumn{2}{|c|}{ Total $(\mu \mathrm{g})$} & \multicolumn{2}{|c|}{ ( $\mu \mathrm{g} /$ foetus) } \\
\hline & & & & $\mathbf{Z n}$ & $\mathrm{Cu}$ & $\mathrm{Zn}$ & $\mathrm{Cu}$ \\
\hline & $\begin{array}{l}15 \\
12 \\
11\end{array}$ & $\begin{array}{c}0.949 \\
0.792 \\
0.621 \\
\text { Mean (over-all) }\end{array}$ & $\begin{array}{l}0.063 \\
0.066 \\
0.056 \\
0.062\end{array}$ & $\begin{array}{l}6.92 \\
5.60 \\
5.66\end{array}$ & $\begin{array}{l}0.98 \\
0.72 \\
0.77\end{array}$ & $\begin{array}{l}0.46 \\
0.47 \\
0.51 \\
0.48\end{array}$ & $\begin{array}{l}0.065 \\
0.060 \\
0.070 \\
0.065\end{array}$ \\
\hline & $\begin{array}{c}\text { No. of } \\
\text { placentae }\end{array}$ & & $\begin{array}{l}\text { Mean wt per } \\
\text { placenta (g) }\end{array}$ & & & \multicolumn{2}{|c|}{$(\mu \mathrm{g} /$ placenta $)$} \\
\hline $\begin{array}{r}3503 \\
\text { A25 } \\
\text { A47 }\end{array}$ & $\begin{array}{l}15 \\
12 \\
11\end{array}$ & $\begin{array}{c}0.816 \\
0.597 \\
0.578 \\
\text { Mean (over-all) }\end{array}$ & $\begin{array}{l}0.054 \\
0.050 \\
0.053 \\
0.052\end{array}$ & $\begin{array}{c}16.0 \\
10.8 \\
9.90\end{array}$ & $\begin{array}{l}\overline{2.65} \\
1 \cdot 74\end{array}$ & $\begin{array}{l}1.06 \\
0.90 \\
0.90 \\
0.96\end{array}$ & $\begin{array}{l}-\overline{22} \\
0 \cdot 16 \\
0.19\end{array}$ \\
\hline & & Uterus wt (g) & $\begin{array}{l}\text { Wt of uterus } \\
\text { per foetus }(g)\end{array}$ & & & & \\
\hline $\begin{array}{r}3503 \\
\text { A25 } \\
\text { A47 }\end{array}$ & & $\begin{array}{c}1.538 \\
1.360 \\
1.274 \\
\text { Mean (over-all) }\end{array}$ & $\begin{array}{l}0 \cdot 103 \\
0 \cdot 113 \\
0 \cdot 116 \\
0 \cdot 110\end{array}$ & $\begin{array}{l}22.5 \\
20 \cdot 6 \\
20.2\end{array}$ & $\begin{array}{l}3 \cdot 72 \\
3 \cdot 26 \\
2 \cdot 88\end{array}$ & & \\
\hline
\end{tabular}

Table 3. The weight and zinc and copper contents of the uterus and placentae of a 'standard' ten-foetus rat at different stages of pregnancy

(Mean values and their standard errors)

\begin{tabular}{|c|c|c|c|c|c|c|c|c|c|c|c|c|}
\hline \multirow{3}{*}{$\begin{array}{l}\text { Day of } \\
\text { pregnancy }\end{array}$} & \multicolumn{6}{|c|}{ Uterus } & \multicolumn{6}{|c|}{ Placentae } \\
\hline & \multicolumn{2}{|c|}{$W t(g)$} & \multicolumn{2}{|c|}{$\operatorname{Zn}(\mu \mathrm{g})$} & \multicolumn{2}{|c|}{$\mathrm{Cu}(\mu \mathrm{g})$} & \multicolumn{2}{|c|}{$W t(g)$} & \multicolumn{2}{|c|}{$\operatorname{Zn}(\mu \mathbf{g})$} & \multicolumn{2}{|c|}{$\mathrm{Cu}(\mu \mathrm{g})$} \\
\hline & Mean & SE & Mean & SE & Mean & SE & Mean & SE & Mean & $\mathbf{S E}$ & Mean & SE \\
\hline $\begin{array}{l}15 \\
18 \\
21\end{array}$ & $\begin{array}{l}3 \cdot 36 \\
4 \cdot 07 \\
4 \cdot 37\end{array}$ & $\begin{array}{l}0 \cdot 138 \\
0 \cdot 116 \\
0 \cdot 232\end{array}$ & $\begin{array}{l}34 \cdot 2 \\
45 \cdot 1 \\
45 \cdot 1\end{array}$ & $\begin{array}{l}1 \cdot 63 \\
2 \cdot 42 \\
2 \cdot 11\end{array}$ & $\begin{array}{c}7 \cdot 01 \\
8 \cdot 28 \\
11 \cdot 1\end{array}$ & $\begin{array}{l}0.451 \\
0.659 \\
0.930\end{array}$ & $\begin{array}{l}1.55 \\
5.00 \\
6.33\end{array}$ & $\begin{array}{l}0.071 \\
0.174 \\
0.422\end{array}$ & $\begin{array}{l}14.9 \\
48.7 \\
56.7\end{array}$ & $\begin{array}{l}1.01 \\
1.98 \\
3.04\end{array}$ & $\begin{array}{c}2.84 \\
15 \cdot 2 \\
20 \cdot 6\end{array}$ & $\begin{array}{l}0.298 \\
0.923 \\
2.37\end{array}$ \\
\hline
\end{tabular}

The growth of foetal and postnatal rats and their accretion of $\mathrm{Zn}$ and $\mathrm{Cu}$

Regression analyses of the logarithms of the weights of the foetuses and their content of $\mathrm{Zn}$ and $\mathrm{Cu}$ with respect to foetal numbers at days 15,18 and 21 of pregnancy showed that these variables were not influenced by the foetal burden.

The weight of, and the amounts of $\mathrm{Zn}$ and $\mathrm{Cu}$ in the individual foetal or postnatal rat at different stages of development are shown in Table 4. The relationships of these measurements to post-conceptional age can be described in terms of one of the standard growth equations, the Gompertz equation, in the form $\log _{e} y=A-B e^{-c x}$ where $y$ is the weight, $\mathrm{Zn}$ content or $\mathrm{Cu}$ content of the developing young and $x$ is the day post-conception. Over the course of pregnancy the values of the constants $A, B$ and $C$ for each of these variables were found to be as follows: for weight (g) $A=30.481, B=39.457$ and $C=0.01499$, the residual standard deviation (RSD) for this equation was 0.11 ; for $\mathrm{Cu}$ content ( $\mu \mathrm{g}), A=15.093$, $B=27.392$ and $C=0.03670$ (RSD $=0.16$ ), and for $Z n$ content $(\mu \mathrm{g}), A=22.410$, $B=32.256$ and $C=0.02762$ ( $R S D=0.10$ ). However, when pregnancy and lactation were considered together, only the $\mathrm{Cu}$ content of the foetal and postnatal rat could be described satisfactorily by a single equation; in this instance, the relevant constants were $A=5.857$, $B=27.997$ and $C=0.09880$ (RSD $=0.24$ ). The inability of the Gompertz equation (or 
Table 4. The weight and zinc and copper contents of the individual foetal and postnatal rat at different stages of development

(Mean values and their standard errors)

\begin{tabular}{|c|c|c|c|c|c|c|}
\hline \multirow{2}{*}{$\begin{array}{l}\text { Day of } \\
\text { pregnancy }\end{array}$} & \multicolumn{2}{|c|}{ Weight (g) } & \multicolumn{2}{|c|}{$\operatorname{Zn}(\mu \mathrm{g})$} & \multicolumn{2}{|c|}{$\mathrm{Cu}(\mu \mathrm{g})$} \\
\hline & Mean & SE & Mean & SE & Mean & SE \\
\hline $\begin{array}{l}12 \\
15 \\
18 \\
21\end{array}$ & $\begin{array}{l}\quad 0 \\
0.350 \\
1 \cdot 54 \\
5 \cdot 32\end{array}$ & $\begin{array}{l}62^{*} \\
0 \cdot 013 \\
0 \cdot 103 \\
0 \cdot 147\end{array}$ & $\begin{array}{c}{ }^{0} \\
2 \cdot 97 \\
16 \cdot 5 \\
77 \cdot 3\end{array}$ & $\begin{array}{l}48^{*} \\
0.096 \\
0.920 \\
1.94\end{array}$ & $\begin{array}{r}0 \\
0.508 \\
2.57 \\
11.5\end{array}$ & $\begin{array}{l}065^{*} \\
0.025 \\
0.210 \\
0.074\end{array}$ \\
\hline $\begin{array}{c}\text { Days } \\
\text { post-partum }\end{array}$ & & & & & & \\
\hline $\begin{array}{r}2 \\
6 \\
14\end{array}$ & $\begin{array}{c}5.77 \\
11.6 \\
24.8\end{array}$ & $\begin{array}{l}0.150 \\
0.23 \\
1.02\end{array}$ & $\begin{array}{l}96 \cdot 1 \\
258 \\
517\end{array}$ & $\begin{array}{c}4 \cdot 23 \\
5 \cdot 70 \\
21 \cdot 7\end{array}$ & $\begin{array}{c}30 \cdot 2 \\
76 \cdot 1 \\
130\end{array}$ & $\begin{array}{c}2.68 \\
6.41 \\
12.0\end{array}$ \\
\hline
\end{tabular}

any other simple growth equation) to describe, over the combined courses of pregnancy and lactation, the weight of or the amount of $\mathrm{Zn}$ in the developing young was related to a temporary decline in the rate of growth and the rate of accretion of $\mathrm{Zn}$ at parturition. This is illustrated in Fig. 1 (derived from the values of Table 4), where it can be seen that, only in the instance of $\mathrm{Cu}$, can these variables be represented by a smooth curve over the combined periods of pregnancy and lactation.

As shown in Table 4 , the mean weight of the $2 \mathrm{~d}$ postnatal rats had increased by only $0.45 \mathrm{~g}$ as compared with that of the $21-\mathrm{d}$ foetuses while the amounts of $\mathrm{Zn}$ and $\mathrm{Cu}$ in them increased by $18.8 \mu \mathrm{g}$ and $18.7 \mu \mathrm{g}$ respectively. As a proportion of the amount already deposited to day 21 of pregnancy, the mean daily fractional increments for weight, $\mathrm{Zn}$ and $\mathrm{Cu}$ content to day 2 of lactation were $0.02,0.06$ and 0.27 respectively.

On differentiation, the Gompertz equation yields the relationship $\frac{1}{y} \cdot \frac{\mathrm{d} y}{\mathrm{~d} x}=B C e^{-c x}$, the left hand side being the fractional (or specific) growth rate which may, therefore, be evaluated at any time $x$. By multiplying through by $y$ the absolute rates of growth or of the accretion of $\mathrm{Cu}$ and $\mathrm{Zn}$ may also be obtained, and both sets of values are shown in Table 5. For the reasons stated previously, only in the instance of $\mathrm{Cu}$ were calculations of the instantaneous and fractional rates of accretion carried beyond parturition; for both the weight and $\mathrm{Zn}$ content of the young rat, the average rates over the three periods following day 21 of pregnancy were calculated from the mean values shown in Table 4.

The ratio of the instantaneous rate of accretion of $\mathrm{Cu}$ to that of body-weight was reasonably constant throughout pregnancy, but that of $\mathrm{Zn}$ to body-weight more than doubled between day 12 and day 21. After birth, however, the instantaneous rate of accretion of $\mathrm{Cu}$ rose rapidly and it can be shown that the time at which this rate reached a maximum (given by $x=\frac{1}{C} \log _{e} B$ ) was at $33.7 \mathrm{~d}$ post-conception when the rate of accretion was $12.7 \mu \mathrm{g} / \mathrm{d}$. The high rate of accretion of $\mathrm{Cu}$ in the postnatal animal was reflected by a substantial rise in the concentration of this metal in the body. From the results shown in Table 3 it was calculated that this rose from $2 \cdot 2$ to $6 \cdot 6 \mu \mathrm{g} / \mathrm{g}$ wet weight between day 21 of pregnancy to day 6 post-partum. In comparison, the concentration of $\mathrm{Zn}$ in the body increased by only $50 \%$ in the same time.

In all instances, the fractional rates of accretion (i.e. the instantaneous rate of accretion 


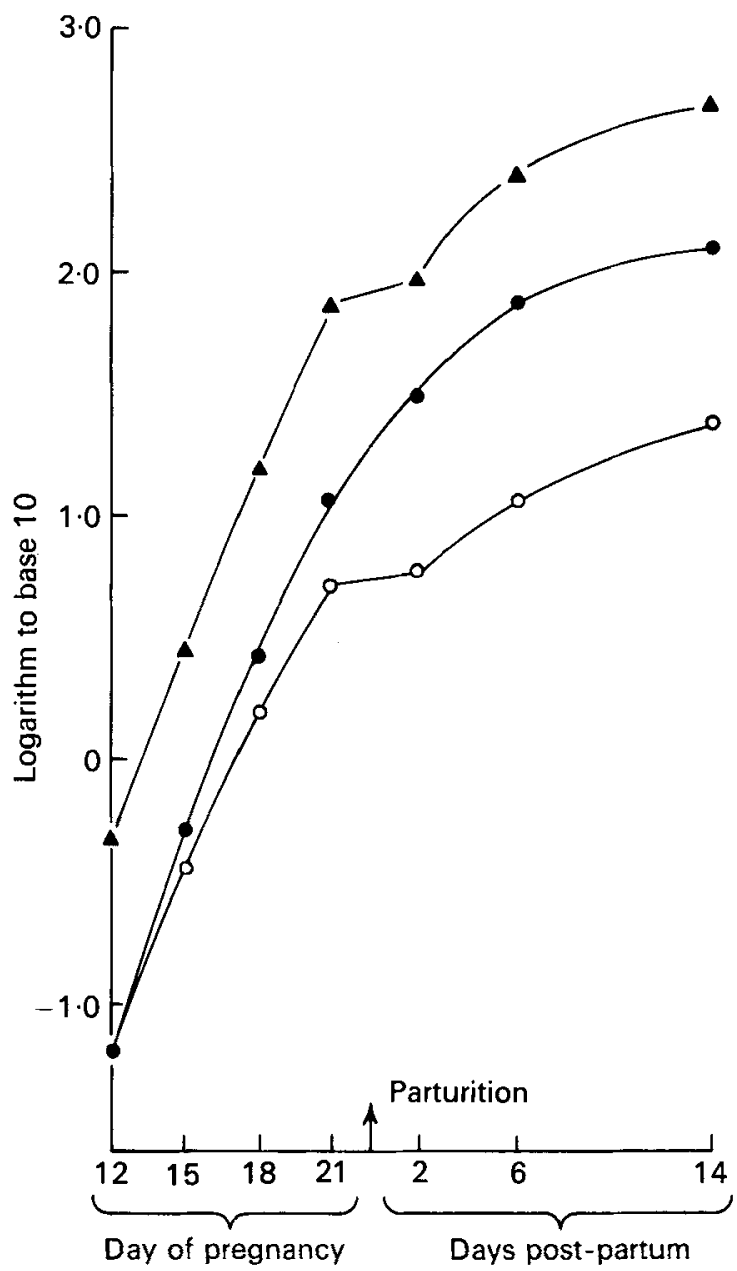

Fig. 1. Semi-logarithmic plot of wet body wt $(\mathrm{O}-\mathrm{O})$, Copper $(\mathbf{O}-\mathbf{)})$ and zinc $(\boldsymbol{\Delta}-\boldsymbol{\Delta})$ contents of the foetal and postnatal rat. The weight was measured in $\mathrm{g}$ and the $\mathrm{Cu}$ and $\mathrm{Zn}$ contents in $\mu \mathrm{g}$.

at a given time as a proportion of the weight, or amount of $\mathrm{Zn}$ or $\mathrm{Cu}$, already deposited to that time) declined throughout the course of pregnancy, the values for the fractional rates of accretion of $\mathrm{Zn}$, and more especially $\mathrm{Cu}$, having declined more rapidly than did those of body-weight. In the post-partum period, all these values tended to approach the same figure.

\section{DISCUSSION}

The results of this experiment showed that the accumulation of $\mathrm{Zn}$ during pregnancy by the maternal body of the rat was negligible in comparison with that of the developing foetuses, and no useful store of $\mathrm{Zn}$ appeared to exist. This result is in agreement with the findings of Spray (1950). In contrast, a store of $\mathrm{Cu}$ was deposited which appeared to be liberated via the milk during lactation. In the rats examined by Spray (1950) the mothers gained about $75 \mathrm{~g}$ in body-weight in the period from conception to a point shortly after delivery of the young; a similar finding was made by Mutch \& Hurley (1974). In comparison, the rats used in our experiment gained less than $20 \mathrm{~g}$ over a similar period. That 
Table 5. The instantaneous and fractional rates of accretion of weight, zinc and copper in the young rat at different stages of development

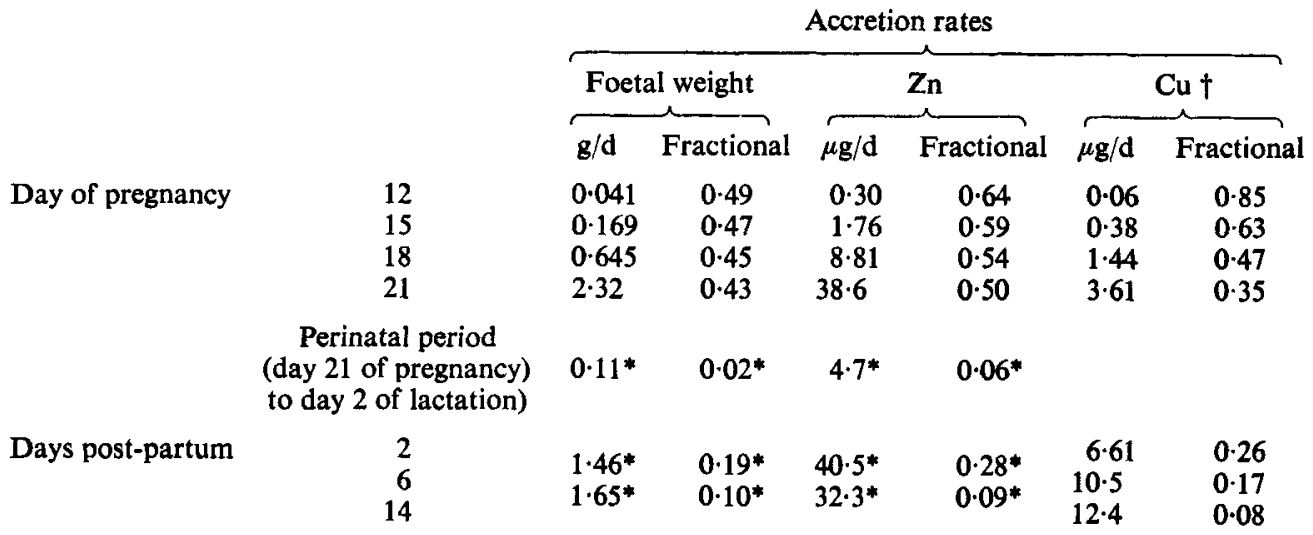

\footnotetext{
* Mean daily accretion rates for periods $21-2,2-6$ and 6-14 d respectively were calculated from mean values (Table 4).

+ The calculations of the instantaneous and fractional rates of accretion of $\mathrm{Cu}$ were based on the constants derived for the Gompertz equation describing the accretion of $\mathrm{Cu}$ over the combined courses of pregnancy and lactation (see text p. 411).
}

this difference was not due to the use of progesterone before mating was demonstrated in separate experiment.

A possible consequence of the smaller weight gain during pregnancy found in this experiment may be a reduction in the contribution made, by depletion of the $\mathrm{Cu}$ stores in the maternal body, to the deposition of $\mathrm{Cu}$ in the postnatal young, as the results of this experiment showed that only about $25 \%$ of the $\mathrm{Cu}$ accrued by them could have arisen from maternal stores. This must be compared with the findings of Spray (1950) that more than $80 \%$ of the $\mathrm{Cu}$ stored by a litter, decreasing in number from nine to seven young between birth and the 15th day of postnatal life, could be accounted for by the decrease in the $\mathrm{Cu}$ content of the maternal body. It would appear that these differences may arise from the use of a different strain of rat, and it would be important to remember when considering nutrient intakes during pregnancy and lactation that such strain-specific differences may exist.

When rats were fed a diet of adequate $\mathrm{Zn}$ content through pregnancy and lactation, only small changes occurred in the $\mathrm{Zn}$ content of bone or soft tissue in comparison with considerable decreases in their content of $\mathrm{Zn}$ when a $\mathrm{Zn}$-deficient diet was fed from the commencement of lactation (Mutch \& Hurley, 1974). Spray (1950) found that very little of the $\mathrm{Zn}$ deposited in maternal tissue during pregnancy was liberated to the postnatal young. Our findings agree with these earlier observations.

The relative demands for $\mathrm{Zn}$ and $\mathrm{Cu}$ made by the foetal or postnatal young were not constant over the stages of pregnancy and lactation examined. From the results of Table 4 it was calculated that, from the 15 th to the 21 st day of pregnancy, about seven times as much $\mathrm{Zn}$ as $\mathrm{Cu}$ was accrued by the foetuses; from day 21 of pregnancy to day 6 of lactation this ratio decreased to 2.8 and then rose to 4.8 between day 6 to day 14 of lactation. These calculations should not be assumed to reflect any necessary variations in dietary supply of these elements as they do not take account of the flux of these metals in the body or of any differences which may exist in the availability of $\mathrm{Zn}$ as compared with $\mathrm{Cu}$ in the milk supply to the postnatal young. However, such changes in the relative rates of accretion 
have not been taken into account in any previous statements of the requirement for these metals during the reproductive cycle.

Descriptions of the growth of foetal and postnatal animals in terms of equations relating the weight of the animal to time post-conception have been discussed by Laird $(1965,1966)$ and Laird, Tyler \& Barton (1965). Our finding that the fractional rate of growth declined with time is in accord with their observations, and only at day 18 of pregnancy was there close agreement with the constant figure of 0.454 derived, for the rat, by Weinbach (1941), which has been cited more recently by Hansard \& Berry (1969). The fractional rates of accretion of $\mathrm{Cu}$ and of $\mathrm{Zn}$ by the developing foetus also declined throughout pregnancy (Table 5).

The results of Tables 3 and 4 show that, from day 18 of pregnancy the demand for both $\mathrm{Zn}$ and $\mathrm{Cu}$ by the products of conception was almost entirely accounted for by the developing foetuses, and as pregnancy advanced, the instantaneous rates of accretion of these metals rose rapidly. At the penultimate day of pregnancy the effective rates of deposition of each metal in a ten-foetus rat would be about 400 and $40 \mu \mathrm{g} / \mathrm{d}$ respectively; these figures should be compared with those of a young rat growing at the rate of $6 \mathrm{~g} / \mathrm{d}$ and retaining 140 and $13 \mu \mathrm{g}$ respectively of $\mathrm{Zn}$ and $\mathrm{Cu}$ each day (Davies \& Nightingale, 1975). The relation of this finding to changes during pregnancy and lactation in the capacity of the maternal gut to absorb these metals is discussed in separate communications (Davies \& Williams, 1976a, $b, 1977)$.

While from day 2 of lactation the mean daily rates of live weight gain of the young rat were numerically less than the instantaneous rate calculated for day 21 of pregnancy, the values for the rate of accretion of $\mathrm{Zn}$ were similar at these times (Table 5). This may be related to an increase in the concentration of this metal in the body which, from day 2 to day 6 rose from $16.5 \pm 0.38$ (SEM) to $22.0 \pm 0.58 \mu \mathrm{g} / \mathrm{g}$ wet weight, the latter figure being close to that which we have observed in more mature animals. This suggests that the rate of accretion of $\mathrm{Zn}$ relative to that of body-weight approached a 'plateau' value at a very early age. In contrast, the maximum rate of accretion of $\mathrm{Cu}$ occurred during the later stages of lactation.

The discontinuity in the logarithmic curves of weight gain and the associated accretion of $\mathrm{Zn}$ which occurred in the early postnatal animals (Fig. 1) may be related to the suggestion of Winick \& Noble (1965) that a loss of water may occur in the early postnatal period. The smooth accumulation of $\mathrm{Cu}$ was unaffected by these changes.

A reduction in the content of $\mathrm{Zn}$ in the diet of the rat, whether at early or late stages of pregnancy has been shown to have severe deleterious effects on the further development of the young (Hurley, Gowan \& Swenerton, 1971; McKenzie, Fosmire \& Sandstead, 1975). The results reported here showed that, early in pregnancy, rapid increases would occur in the concentration of each metal in the foetus. If these demands are not met, presumably by the maintenance of an adequate content of $\mathrm{Zn}$ and $\mathrm{Cu}$ in the maternal blood, anomalies in the distribution of these metals in the developing embryo or foetus would be inevitable. In the instance of $\mathrm{Zn}$ it appeared that satisfaction of the demand made by the foetal or postnatal animal is wholly dependent on the assimilation by the mother of adequate intakes of $\mathrm{Zn}$ at all stages of pregnancy and lactation.

While the absolute requirements for $\mathrm{Cu}$ by the developing rat foetus were much smaller than those for $\mathrm{Zn}$, they increased rapidly during lactation. In this species, therefore, it would appear that while a marginal maternal deficiency of $\mathrm{Cu}$ might be expected to be less deleterious to the young developing in utero than would be the case for $\mathrm{Zn}$ the greater effect would occur in the deposition of $\mathrm{Cu}$ stores in the postnatal young, though, as mentioned earlier, such effects may be strain- or breed-specific. 


\section{R. B. Williams, N. T. Davies and I. McDonald}

Miss Rosemary Kemp and Mr S. J. Miller gave valuable assistance with the analysis of the samples and Mrs Norma McKenzie carefully looked after the rats.

\section{REFERENCES}

Davies, N. T. \& Nightingale, R. (1975). Br. J. Nutr. 34, 243.

Davies, N. T. \& Williams, R. B. (1976a). Proc. Nutr. Soc. 35, 4A.

Davies, N. T. \& Williams, R. B. (1976b). Proc. Nutr. Soc. 35, 5A.

Davies, N. T. \& Williams, R. B. (1977). Br. J. Nutr. 38, 417.

Hansard, S. L. \& Berry, R. K. (1969). In Animal growth and nutrition, p. 55 [E. S. E. Hafez and I. A. Dyer, editors]. Philadelphia, Pa: Lea \& Febiger.

Hurley, L. S., Gowan, J. \& Swenerton, H. (1971). Teratology 4, 199.

Laird, A. K. (1965). Growth 29, 249.

Laird, A. K. (1966). Growth 30, 349.

Laird, A. K., Tyler, S. A. \& Barton, A. D. (1965). Growth 29, 233.

McKenzie, J. M., Fosmire, G. J. \& Sandstead, H. H. (1975). J. Nutr. 105, 1466.

May, D. \& Simpson, K. B. (1971). J. Inst. anim. Tech. 22, 133.

Mutch, P. B. \& Hurley, L. S. (1974). J. Nutr. 104, 828.

Spray, C. M. (1950). Br. J. Nutr. 4, 354.

Spray, C. M. \& Widdowson, E. M. (1950), Br. J. Nutr. 5, 332.

Weinbach, A. P. (1941). Growth 5, 217.

Winick, M. \& Noble, A. (1965). Develop. Biol. 12, 451. 